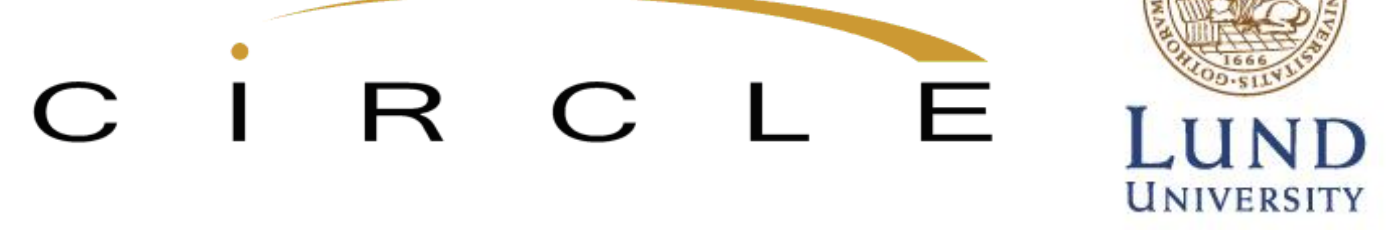

Paper no. 2013/15

\title{
The Geography and Structure of Global Innovation Networks:
} A Knowledge Base Perspective

\author{
Ju Lie (ju.liu @circle.lu.se) \\ CIRCLE, Lund University
}

Cristina Chaminade (Cristina.chaminade@circle.lu.se)

CIRCLE, Lund University

Bjørn Asheim (bjorn.asheim@circle.lu.se)

CIRCLE, Lund University

\begin{abstract}
This is a preprint of an article whose final and definitive form will be published in European Planning Studies (c) [2013] [copyright Taylor \& Francis]; European Planning Studies is available online at informaworld ${ }^{\mathrm{TM}}$ www.informaworld.com/smpp/title content=t713417253.

Citations to and quotations from this work should reference that publication. If you use this work, please check that the published form contains precisely the material to which you intend to refer.
\end{abstract}

This version: September 2012

Centre for Innovation, Research and Competence in the Learning Economy (CIRCLE)

Lund University

P.O. Box 117, Sölvegatan 16, S-221 00 Lund, SWEDEN

http://www.circle.lu.se/publications 
WP 2013/15

The Geography and Structure of Global Innovation Networks: A Knowledge Base Perspective

Ju Liu; Cristina Chaminade; Bjørn Asheim

\section{ABSTRACT}

This paper explores the geography and structure of global innovation networks (GINs) of two multinational companies belonging to industries with different knowledge bases. It contributes to existing literature on knowledge bases, by studying both intra-firm and inter-firm GINs. By means of social network analysis based on primary data, we identify two different forms of GINs, namely the globallyorganised model and the locally-organised model. The paper finds that, in addition to influencing the geographic spread of a GIN, the knowledge base also influences the way that a GIN is organised.

JEL Code: F23, O32

Keywords: global innovation network, multinational companies, knowledge base, structure, geography, social network analysis

Disclaimer: All the opinions expressed in this paper are the responsibility of the individual author or authors and do not necessarily represent the views of other CIRCLE researchers. 


\title{
The Geography and Structure of Global Innovation Networks:
}

\author{
A Knowledge Base Perspective \\ Ju Liu Cristina Chaminade Bjorn Asheim \\ CIRCLE, Lund University
}

\begin{abstract}
:
This paper explores the geography and structure of global innovation networks (GINs) of two multinational companies belonging to industries with different knowledge bases. It contributes to existing literature on knowledge bases, by studying both intra-firm and inter-firm GINs. By means of social network analysis based on primary data, we identify two different forms of GINs, namely the globally-organised model and the locally-organised model. The paper finds that, in addition to influencing the geographic spread of a GIN, the knowledge base also influences the way that a GIN is organised.
\end{abstract}

\section{INTRODUCTION}

Innovation is a networked phenomenon. Firms and other organisations innovate in continuous interaction with other organizations in their near but sometimes also distant environment (Lundvall, 1992, Freeman, 1987). The geography of innovation has long been discussed by economic geographers in the literature on innovative clusters (Audretsch and Feldman, 1996, Feldman, 2000, Lissoni, 2001, Giuliani, 2007, Moodysson et al., 2008), regional innovation systems (Asheim and Isaksen, 1997, Asheim, 2002, Cooke, 1996) and innovation networks (Cooke, 1996, Sternberg, 2000, Love and Roper, 2001, Boschma and Frenken, 2001). Economic geographers have argued that due to the tacit nature of knowledge and its sticky character, innovation networks tend to be bounded to certain territories. Geographic proximity often enhances trust and thus facilitates the exchange of knowledge among 
organizations co-located in a certain territory.

Since the mid nineties, economic geographers have been increasingly concerned with the global spread of innovation activities (Coe and Bunnell, 2003, Chen, 2004, Gertler and Levitte, 2005, Dankbaar, 2007, Ernst, 2002, Fifarek and Veloso, 2010). The increasing globalisation of economic activities has not diminished the role of the region (Dickens, 2007, Gertler, 2006). Instead, regions have become knowledge hubs in GINs (Chaminade and Vang, 2008, Gertler and Levitte, 2005). As knowledge continues to be bounded to certain territories, these areas become poles of attraction for agents involved in knowledge intensive activities. For example, multinational companies (MNCs) are attracted to certain regions in the world that have accumulated specific competences that are difficult to acquire (Narula and Zanfei, 2004, Cantwell and Piscitello, 2007, Cantwell and Piscitello, 2005, Lewin et al., 2009). Furthermore, clusters that are able to maintain high levels of local buzz and simultaneously, create channels that tap into global flows of knowledge show higher levels of growth and dynamism (Bathelt et al., 2004). Local and global linkages are, therefore, complementary.

Asheim and Coenen (2005) extended the local-global debate by arguing that the extent to which an industry becomes more localised or globalised is highly contingent on its knowledge base. Firms in industries dominated by the synthetic knowledge base tend to exchange knowledge with geographically close partners while firms in industries dominated by the analytical knowledge base may tap more often into geographically distant sources of knowledge (Asheim and Coenen, 2005, Martin and Moodysson, 2011a, Martin and Moodysson, 2011b, Moodysson et al., 2008). Synthetic knowledge tends to differ from place to place, while analytic knowledge is more codified, abstract and universal. As a consequence, innovation networks that rely on synthetic knowledge tend to be more local, while innovation networks built on analytic knowledge tend to be more global.

Despite its value, the existing literature is based exclusively on the analysis of inter-firm networks, almost completely neglecting intra-firm relationships (Coe et al., 
2008) which play a critical role in how global networks operate and impact (Dicken and Malmberg, 2001). The interaction between the intra-firm and inter-firm networks influences the geographic pattern of a GIN as well as its structure. Structure is defined here as the pattern of relations in the network. The structure of a network reflects how the network is organised and suggests 'possible ways in which we could exploit it to achieve certain aims' (Newman, 2003:180). Thus, when studying the geography and structure of GINs, it makes sense to conceive of the firm as a relational intra-firm network embedded in wider networks of external actors (Coe et.al, 2008).

The aim of this paper is to address this research gap by investigating the influence of knowledge bases on the geography and structure of the innovation networks in two MNCs whose internal and external innovation networks are both globally spread. Using social network analysis, we analysed the primary relational data of the case firms' GINs and identified their relational patterns to see how their GINs are organised. The evidence shows that the knowledge base influences the way that MNCs organise their innovation networks in a global scope.

The rest of the paper is presented in four sections. The second section includes the literature review and theoretical framework. The third section is the analytical and methodological framework, which includes the case study design, selection of case firms, the data collection methods, and analysis of the data. The fourth section presents the main findings. The fifth section provides a discussion of the findings and concludes the article.

\section{THEORETICAL FRAMEWORK}

In this section, we will review the literature on the geography of innovation networks and introduce the theoretical framework based on the knowledge base approach of economic geography.

Innovation is the result of the continued interactions between firms and other organizations (Freeman, 1987, Lundvall, 1992, Nelson, 1993) as well as between different individuals and departments within one organization (Grant, 1996). It is 
through interactions that tacit and explicit knowledge is transferred and new knowledge is created. Networks are, therefore, the basis for interactive learning and innovation.

Contemporary economic geography aims at understanding the geography of these networks particularly by studying the nature of the knowledge being transferred. Traditionally, it has been argued that when knowledge was mainly tacit, innovation networks were likely to be geographically bounded because proximity with other members of the network facilitated the exchange of non-codified or tacit knowledge (Storper, 1992, Storper and Venables, 2004). Only codified knowledge could be transferred across geographic distances. Tacit knowledge was 'sticky' and was therefore difficult to transfer across large spatial distances. This led to an overemphasis on the importance of co-locality for innovation. The literature on industrial districts (Becattini, 1990, Markusen, 1996) and clusters include good examples of this (Porter, 1998, OECD, 2001, DE BRESSON, 1986, Nadvi and Schmitz, 1999).

The gradual decline of some traditional industrial districts in Europe due to lockin as well as the increasing evidence of clusters in developing countries with very strong international linkages (Giuliani et al., 2005, Loebis and Schmitz, 2005, Schmitz, 2000) brought to light the importance of global "pipelines" and the interaction between global and local networks of innovators (Bathelt et al., 2004). This 'international turn' runs in parallel with a wider critique by economic geographers and innovation scholars to the rather dichotomous way of looking at types of knowledge (tacit-local versus codified-global), its transferability and its geography. Both tacit and codified knowledge are necessary to the innovation process or, more generically, the process of knowledge creation (Nonaka and Takeuchi, 1995). The coexistence of tacit and codified knowledge in both organisations and individuals (Nightingale, 1998) makes the separation between them virtually impossible in practice. Furthermore, both tacit and codified knowledge can be transferred within networks and across spatially distant locations (Gertler, 2008); notably when the lack 
of geographic proximity is compensated by other dimensions of proximity (Boschma, $2005)^{1}$.

Some scholars in this line of thought argue that, due to the different nature of their knowledge bases, industries are likely to differ in the degree of globalization of their innovation networks. The local-global interaction also differs across industries (Asheim and Coenen, 2005; Asheim and Gertler, 2005; Moodysson et al., 2008) and activities (Moodysson, 2008) and depends on the type of knowledge base that is dominant in that particular industry. Asheim et al. (2007) distinguish between three types of knowledge bases: the analytical, synthetic and symbolic knowledge base. In this paper, we will focus only on the first two types of knowledge bases, namely analytical and synthetic.

Analytic knowledge refers to industrial settings where scientific knowledge is highly important and where knowledge creation is often based on deductive rational processes and applications of scientific laws. It is the equivalent of science-based knowledge creation. Collaboration usually takes place between research organizations or research units. Knowledge is often highly abstract, universal and often codifiable in the form of formulas and scientific laws. Due to these characteristics, knowledge creation can take place across distant locations compared with firms in other knowledge-based industries which rely more on local sources of knowledge (Martin and Moodysson, 2011b). Knowledge can be transferred through communication technologies like the Internet. Typical examples of these industries include the biomedical industry (drug development) and sub-sectors of the information and communication technologies (ICT) sector.

Synthetic knowledge refers to industrial settings wherein innovation takes place mainly through the application of existing knowledge or through new combinations of knowledge. It is the equivalent of an engineering-based learning process. In contrast to the analytical knowledge base, synthetic knowledge is built through inductive processes often based on solving specific problems. Knowledge is context-specific

${ }^{1}$ Cognitive, organizational or social proximity may compensate the lack of geographic proximity creating the conditions for the transferability of tacit knowledge across different geographic scales. 
and has a strong tacit component. In this case, collaboration typically takes place with suppliers and users, who provide the product specifications. Face-to-face interaction is very important in these industries and, as a consequence, so is spatial proximity. Firms in these industries tend to establish collaborations with other organizations in close geographic proximity (Asheim et al, 2007, Asheim and Coenen, 2005). In addition, synthetic knowledge bases are often subject to specific national norms or regulations which vary significantly from region to region or country to country (Martin and Moodysson, 2011a, 2011b). Typical examples of these industries include food processing, automotive components and, in general, mechanical engineering.

The main characteristics of these two types of knowledge are summarised in Table 1.

Table 1. The main characteristics of synthetic and analytic knowledge base

Analytic

Synthetic

(Science-based)

(Engineering-based)

- Innovation by creation of new knowledge

- Importance of scientific knowledge often based on deductive processes and formal models

- Innovation by application or novel combination of existing knowledge

- Research collaboration between firms and research organisations and between research units

- Dominance of codified knowledge due to documentation in patents and publications

- More radical innovation

- More globally spread
- Importance of applied, problem-related knowledge (engineering)

- Interactive learning with clients and suppliers

- Dominance of tacit knowledge due to more concrete know-how, craft and practical skill

- Mainly incremental innovation

- More national and regionally spread

Source: Asheim and Gertler (2005) and Martin and Moodysson (2011)

The analytic-synthetic-taxonomy has three main merits. First, it integrates the tacitexplicit tandem and the science-engineering distinction. Second, it moves away from the tacit-explicit-dichotomy that is prevalent in economic geography by introducing a much more nuanced explanation of the geography of knowledge interactions in specific industries and the motivations for localisation/globalisation, in particular. Third, it provides researchers with an analytical tool to predict and explain why 
certain industries are more globalised than others, with regards to their external knowledge sourcing.

With few exceptions, (e.g. Moodysson, 2008) scholars in the knowledge base approach, focus their analysis on inter-firm relationships, ignoring almost completely the internal linkages of the firm. Such remissness mainly results from the major focus of economic geographers on small-and-medium-sized-enterprises (SMEs) whose internal connections are mainly local and excludes the MNCs, particularly those that have multiple plant sites. This is a critical missing component in the analysis of the structure and geography of innovation networks. MNCs are some of the most important agents in internationalisation. Innovation networks that involve MNCs are different in at least one respect: knowledge creation encompasses the use of both internal and external networks that span across different geographic areas (Castellani and Zanfei, 2006, Zanfei, 2000, Barnard and Chaminade, 2011). Knowledge sourcing thus takes place through inter-firm as well as intra-firm networks.

If knowledge bases influence the geographic patterns of knowledge creation in inter-firm networks, we may expect that they also exert influences on the pattern of intra-firm network relations. Thus, knowledge bases should influence the way GINs are organised as a whole. In order to explore this, we focus on the GINs of two MNCs belonging to industries dominated by the analytical and the synthetic knowledge base, respectively.

The method used in our study will be described next.

\section{RESEARCH METHOD}

In this section, we introduce the design of the case study, the selection of case firms, the data collection methods, and the analysis of data.

\section{Design of the comparative case study}

This paper attempts to analyse the geography and structure of the GINs of two MNCs and the influence of knowledge bases, namely the analytic and synthetic 
knowledge base, on the pattern of relations within the GINs . With this intention, we conduct a social network analysis on two MNCs operating in the analytic and synthetic knowledge-based industries, respectively. We adopted a structural approach of social network analysis to explore the relational pattern of the GINs. The structural approach neglects the content of the relations and the attributes of the actors in a network but puts emphasis on the pattern of interactions among the actors (Borgatti, 2003). The structural approach allows a closer examination of how the case firms' GINs are organized by focusing on the social relations among actors rather than the value-adding functions ( $R \& D$, production, financing, marketing, etc.) of the actors, which are mostly similar in the two case firms.

\section{Selection of case companies}

Case company selection was based on four criteria, namely, the firm's global location, firm's production and innovation capabilities, firm size, and the knowledge base of the industry within which the case firms operate. Based on these four criteria, we selected a company in the telecommunication industry and a company in the automobile safety product industry. For confidentiality reasons, we refer to these two firms as TELE and AUTO.

Both companies are headquartered in Scandinavia and have a strong global presence in Europe, Asia-Pacific, North and South America and Africa. Both firms have strong innovation capabilities. TELE is a world-leading provider of telecommunications equipment and related services to automotive and fixed network operators. TELE's patents comprise one of the industry's strongest portfolios. AUTO is also a world-leading company, specialised in airbags, seatbelts, safety electronics, steering wheels, and seat components. AUTO's patent portfolio is very extensive, ranking at the top of the automobile components industry, particularly regarding safety. Both firms are large companies with more than 1000 employees.

Even though the knowledge base of an industry is always a complex mixture of both analytic and synthetic knowledge, one can still identify the dominant knowledge base of an industry according to the characteristics of its main technology group. In 
this paper, TELE is selected as a case firm from an analytic-knowledge-based industry (Asheim and Gertler, 2005). In the telecommunication industry, as suggested by Asheim et al. (2007) and verified by the VP of TELE during our interview, formal R\&D plays an important role. In 2005, the world's biggest telecommunication company ranked fourth in terms of international patent applications with the World Intellectual Property Office (WIPO). The automobile safety company is selected as a case firm from a synthetic-knowledge-based industry (Asheim and Gertler, 2005). In automobile industry, R\&D plays a smaller role relative to analytic-knowledge-based industries. As pointed out by the VP of AUTO, this industry typically responds to the need to solve specific problems that come up in the firm's interaction with customers and suppliers. In 2005, the world's biggest automobile safety product manufacturer was ranked $171^{\text {st }}$ in terms of international patent applications with the WIPO, a much lower ranking than the world's biggest telecommunication company. Automobile safety products are often one-off products which are produced in a relatively small series in order to fit into a specific car model for a specific market. Knowledge creation is often an inductive process based on testing, experimentation, computerbased simulation, or practical work. Innovation is more geared towards reducing cost, increasing efficiency and reliability of new solutions. These characteristics of the automobile safety industry exhibit the characteristics of synthetic knowledge based industry suggested by Asheim and Gertler (2005).

\section{Collection of data}

Data sources used in this study include interviews, questionnaires, websites, corporate internal reports and documents, and press news. The questionnaire was developed and administered to elicit responses from the Vice Presidents (VPs) for research from the two case firms. In total, four interviews were conducted. Each interview lasted between one to three hours and all interviews were recorded and transcribed. The interviews were conducted between the years 2010 and 2011 and took place at the headquarters of the case firms and one of their international 
branches.

The interviews included questions on the background of the company and the industry, such as the history of the company, the organisational structure of the company, their strategy of innovation, the technology nature and competition in the industry, etc. The questions then focused on the relationship between the internal actors, namely the headquarters' functional departments/groups and the subsidiaries at three geographic levels and the relationships between the internal actors and the outside organisations. The informants were reminded constantly that all the relationships should be relevant to the companies' technological innovation activities in order to avoid any confusion of mixing daily operations and innovation.

Potential informant bias is addressed in three ways. First, we triangulated information with multiple data sources such as internal documents of the company, annual reports, web sites, and specialized journals in the sector. The use of multiple sources provides more accurate information and improves the robustness of the results (Jick, 1979). Second, we selected highly knowledgeable informants. The VPs for research or $R \& D$ operation have a deep and wide-ranging understanding of the innovation activities in the company at all levels. Third, we used the "courtroom questioning" technique to focus on factual accounts (Lipton, 1977; Huber and Power, 1985). We asked the informants to specify the activities involved in each specific relationship.

\section{Analysis of data}

GIN in this paper refers to a set of relationships of the case company aiming at technological innovation, both product and process innovation. Services innovation is excluded in this research.

The study distinguishes two groups of GIN actors, the intra-firm group and the inter-firm group. The intra-firm network refers to the set of relations among the functional departments or groups within a company's headquarters and its subsidiaries. Following Porter's (1985) taxonomy, this study identified the following 
headquarters' functional departments: production, $R \& D$, marketing, finance, human resource and purchasing/sourcing. As to the subsidiaries of the case companies, the study distinguishes between subsidiaries for R\&D, production, and marketing. The intra-firm network captures the relationships among the different departments at the headquarters as well as between the headquarters' departments and the subsidiaries around the world. Those subsidiaries include R\&D centres and laboratories, manufacturing plants, and sales offices. The inter-firm network refers to the set of relations among the case company (headquarters and subsidiaries) and the outside collaborators. The outside collaborators include universities and research institutes, customers, suppliers, competitors, and government agencies.

In both intra-firm and inter-firm networks, we identified three geographic levels: local, national, and international. The local level refers to the region where the case companies are headquartered. The national level refers to the rest of the country excluding the region of the headquarters. The international level refers to the rest of the world.

The names and abbreviations of the actors of the GINs are shown in Table 2. Geographic locations are identified as L (local), N (National and I (International). For example, the actor LCST refers to Local CuSTomers in the headquarters region. NGOV refers to National GOVernment agencies. ISRD refers to International Subsidiaries for R\&D which locate in other countries.

Table2. Names and abbreviation of intra- and inter-firm network actors of the GINs

\begin{tabular}{llll}
\hline & Intra-firm network actors & & Inter-firm network actors \\
\hline R\&D & R\&D Department & CST & Customers \\
\hline PRD & Production coordinator & SPL & Suppliers \\
\hline HR & Human Resource Department & CPT & Competitors \\
\hline MKT & Marketing Department & GOV & Government agencies \\
\hline FIN & Financial Department & U\&R & Universities \& research institutes \\
\hline PCH/SOC & Purchasing Department/ & & \\
& Sourcing Department & & \\
\hline SPD & Subsidiaries for production & & \\
\hline SRD & Subsidiaries for R\&D & & \\
\hline
\end{tabular}




\begin{tabular}{ll}
\hline SMK & Subsidiaries for marketing \\
\hline
\end{tabular}

The relations in the innovation networks are both formal and informal relationships for:

1) accessing openly available information at a low cost, such as membership in trade associations, attendance at conferences, and subscriptions of journals;

2) acquiring technology and knowledge without active cooperation with the source, such as purchasing machinery, equipment, hiring people, or using contract research and consultant service; and

3) actively participating in joint innovation projects.

The relational data on these ties were collected through a roster recall method (Wasserman and Faust, 1994). Each case company was presented with a complete list (roster) of the actors in the network and was asked the following questions:

Q1: Do the following actors contact each other for your company's production/innovation activities?

Q2: If they do, are these connections for production, for innovation, or for both?

Q3: What is the strength of these connections in terms of the intensity ${ }^{2}$ of their collaboration and the frequency with which they contact each other? The strength was measured in a five-point Likert scale, where 5 denotes 'very strong' and 1 denotes 'very weak'. 0 denotes 'no connection'.

We mapped the GINs of the two case companies by using the NetDraw tool of multi-dimensional scaling (MDS) with a principal component layout. MDS is a set of techniques that is used in network analysis to assign locations to nodes in multidimensional space.

To explore the geography and the structure of the case firm's GINs, we conducted two network analyses, namely key connection analysis and structural equivalence

\footnotetext{
${ }^{2}$ Intensity refers to the degree of scale and scope of the collaboration. In this paper the scale depends on the financial and human resources invested in the collaboration. The scope depends on the form of collaborative activities such as shared membership in the trade association, contract research, and joint research project.
} 
analysis. In addition, we used quotations from the interviews to provide a more detailed insight and understanding of the geography and structure of the GINs.

Key connection analysis identifies the most important connections of the GINs. The key connections carry the most important networking activities in the networks. Key connection analysis reveals information about how the network is mainly organised and by whom. A connection or a group of connections are considered to be important if the whole network is disrupted when this connection or the group of connections were to be removed. Conversely, the connection is deemed unimportant if the absence of this connection or these connections do not create any disruption to the whole network. By distinguishing the geographic location of the actors involved in key connections, we obtain an insight into the geographic pattern of the connections that are playing an important role in the network. For identifying the key connections, we adopted a lambda set approach which ranks each of the relationships in the network in terms of importance by evaluating how much of the flow among actors in the network goes through each link of the GIN. We select three connections with the highest cut-off value in the hierarchical lambda set partitions. These three connections are the top three most important connections which, if disconnected, would greatly disrupt the flow between all of the actors.

The Structural equivalence analysis identifies actors belonging to categories according to their pattern of relations with other actors. The structural equivalence in a social network results from similar patterns of relations among actors and from similar social roles or social behaviour in the network (Lorrain and White, 1971). It is an indicator of the actors' social roles in the network ${ }^{3}$. Two actors are structurally equivalent if they have identical relations with the other actors. Thus, they are considered to be in the same category and embedded in the same social environment. They are, therefore, expected to yield the same outcome - for example, to adopt the

\footnotetext{
${ }^{3}$ In sociology, the most commonly used example of structural equivalent actors is parents. A parent is a social role defined by the relation with at least one partner and one child. It does not matter what the name of the partner or child is. Once we find out the structural equivalent actors in the family network, we understand how the family network is organised.
} 
same attitude, behaviour or performance (Burt, 1987) regarding decisions for transferring knowledge to other actors. In short, structurally equivalent actors play the same social role in GINs. The social roles of different categories of actors reflect the way a GIN is organised as a social network. By analysing the geographic location of the actors who are structurally equivalent, we reveal the structure and geography of GINs.

\section{GEOGRAPHY AND STRUCTURE OF INNOVATION NETWORKS: EVIDENCE AND DISCUSSION}

In this section, we will first present the main empirical findings of the paper and then identify two models of the structure of GINs. Finally, we will discuss the different nature of the knowledge bases of the case firms' industries and their relation with the two different GIN structure models.

\subsection{GIN of case firm in an analytical knowledge-based industry}

When inspecting the most important connections of TELE's GIN, we find that the R\&D department and subsidiaries constitute the most important connections at all geographic levels (see Figure 1). The most important connection consists of relations among the headquarters' R\&D department and local R\&D subsidiaries. The second important connection consists of relations among headquarters' R\&D department, local $R \& D$ subsidiaries, and national $R \& D$ subsidiaries. The third important connection in the GIN of TELE consists of relations among all the four levels of R\&D organisations, namely the headquarters' R\&D department and local, national, and international R\&D subsidiaries. In other words, relationships involving different R\&D units within the firm carry the greatest communication flow. This means that if we remove $R \& D$, the structure of TELE's GIN will be most disrupted. This holds at all geographic levels. It seems that $R \& D$ actors play the biggest and most important role in the TELE's GIN. The strong presence of R\&D units in the important connections in the network reflects a model of knowledge creation based on research and scientific 
discovery, such as the one that characterizes analytical knowledge bases.

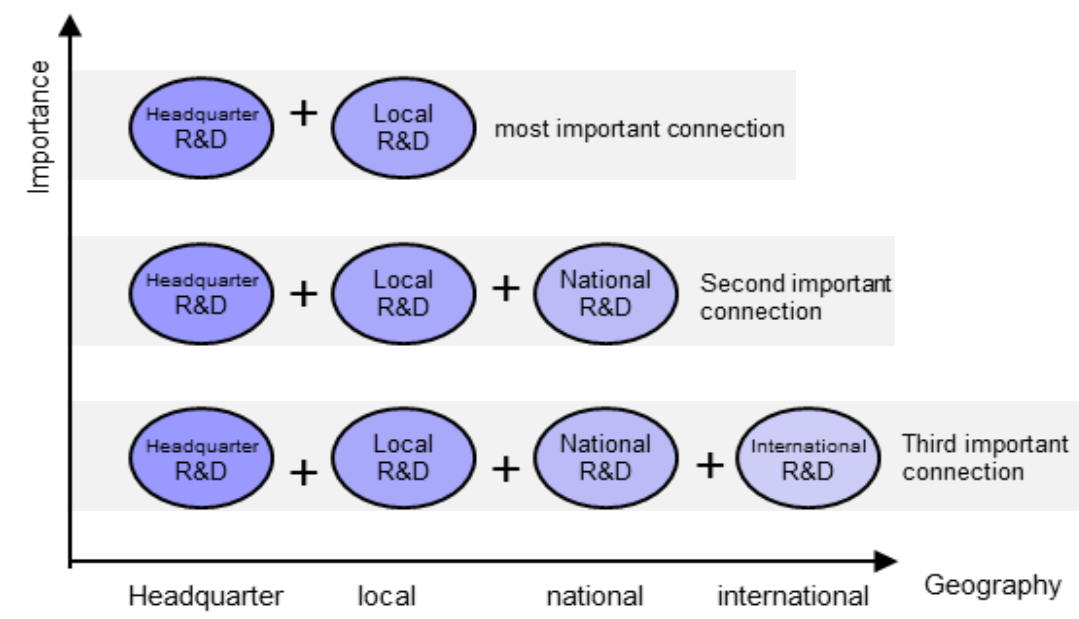

Figure 1. TELE's top3 most important connections in its GIN

To understand the structure and geography of the network, we use the structural equivalence analysis described earlier. The sociogram of the GINs are plotted with NetDraw MDS with a principal component layout. In these sociograms, when a group of nodes are close to each other, it means they have similar pattern of relations; that is, they are connected by the same nodes and they have a similar number of connections and distance to all other nodes. These nodes are structurally equivalent. As we introduced before, structurally equivalent actors are considered to play the same social roles and embedded in the same social environment which reflects the way that a GIN is organised as a social network.

In TELE's GIN, structurally equivalent actors belong to the same function. As shown in Figure 2, the actors aggregated together are for the same value-adding function (R\&D, marketing, production, etc), independent of their location. They are linked to each other but also to other actors of their internal and external network, also independent of their location. 


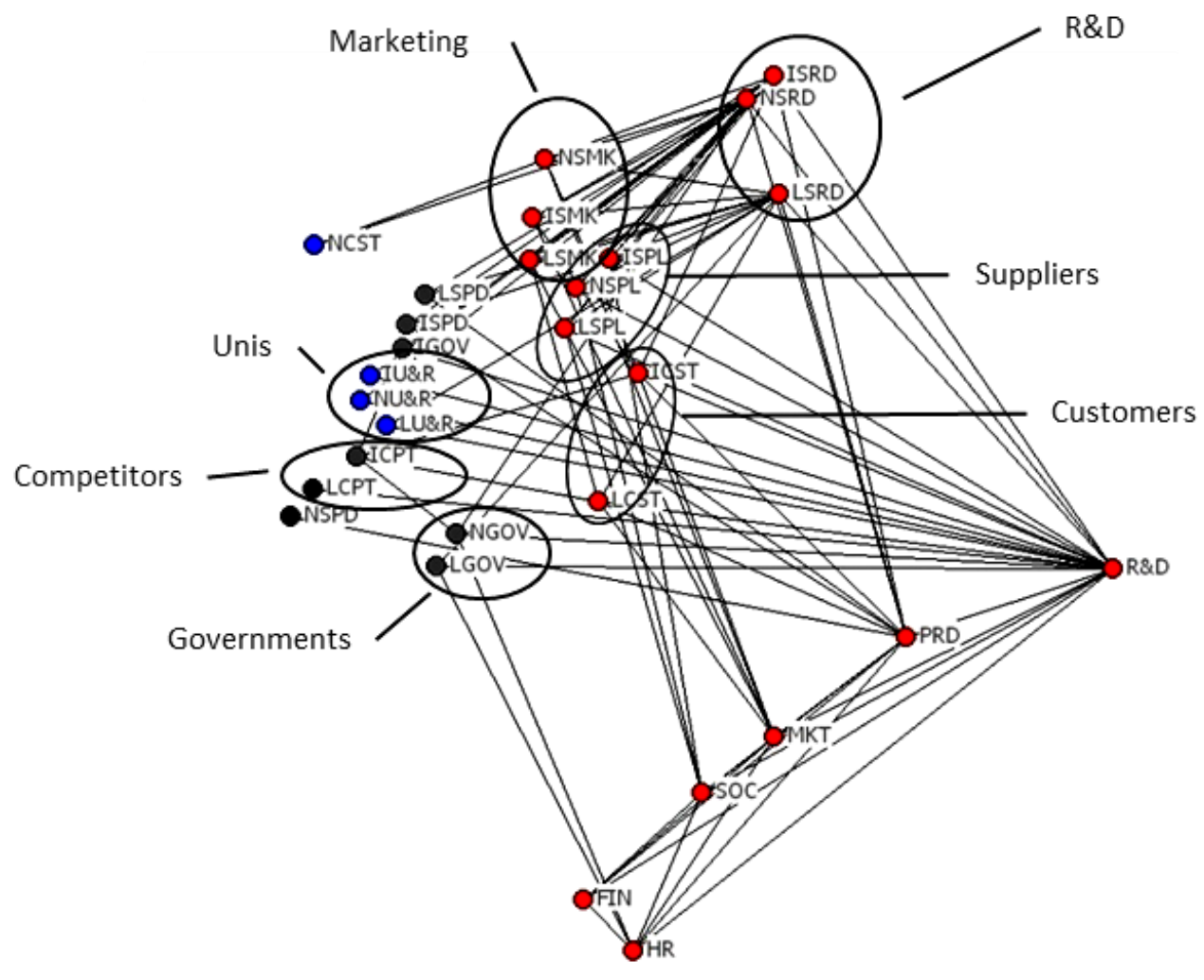

Figure 2. Structure of TELE's GIN

This means, TELE's GIN is more globally organised. The globally-organised characteristic of TELE's GIN is explained by its VP.

"Taking the relationship between R\&D and the suppliers as an example, our suppliers are global. So it is "all-talk-to-all". An R\&D branch in the headquarters will talk to all levels of suppliers within their product line. If they are responsible for that machine, then they need to form their own network (...) it becomes the same thing for any R\&D site regardless if it is in the European headquarters or in Beijing. If they are responsible for product development, they need to talk to, for example, all the marketing units at all levels who can provide relevant information. That's why it becomes a global 'mess'.”

\subsection{GIN of case firm in a synthetic knowledge-based industry}

In the case of AUTO, the most important connections are within or with the 
headquarters' departments (see Figure 3). The most important connection consists of relations among the headquarters' production department and marketing department. The second important connection consists of relations among headquarters Production, Marketing, and R\&D Department, as well as international subsidiaries for production. The third important connection consists of relations among headquarters Production, Marketing, R\&D, and Financial Department, as well as national and international subsidiaries for production. Thus, we can see that the headquarters is the most important communication hub in the AUTO's GIN, in general, and the Production and Marketing Department are the most well connected actors in the GIN. The fact that production and marketing are the key functions in the innovation network (and not R\&D) reflects the nature of the knowledge-base in that particular industry. Knowledge is highly tacit and customer-specific and it is created through interactions with customers and suppliers, which, functionally, are mediated by the marketing and production departments of the organization.

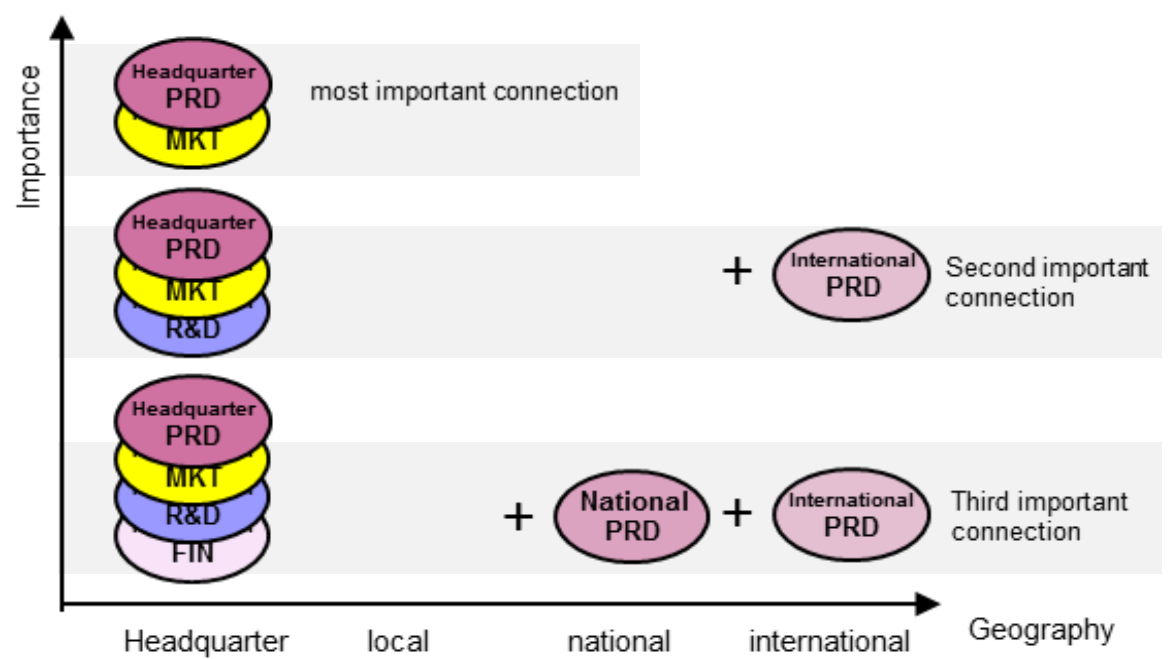

Figure 3. AUTO's top3 most important connections in its GIN

Geographically, AUTO's GIN is organized in a completely different manner from TELE's GIN. Structurally equivalent actors are those who locate within the same geographic scope (see Figure 4), such as headquarters, local, national and international level. These results suggest a great overlap between the geography and structure of the innovation and production networks in this particular industry. Both 
follow what Dickens (2007; 356) labels as "regionalized networks", in which operations at global scale are organized regionally, with distinctive marketing and production networks in each market.

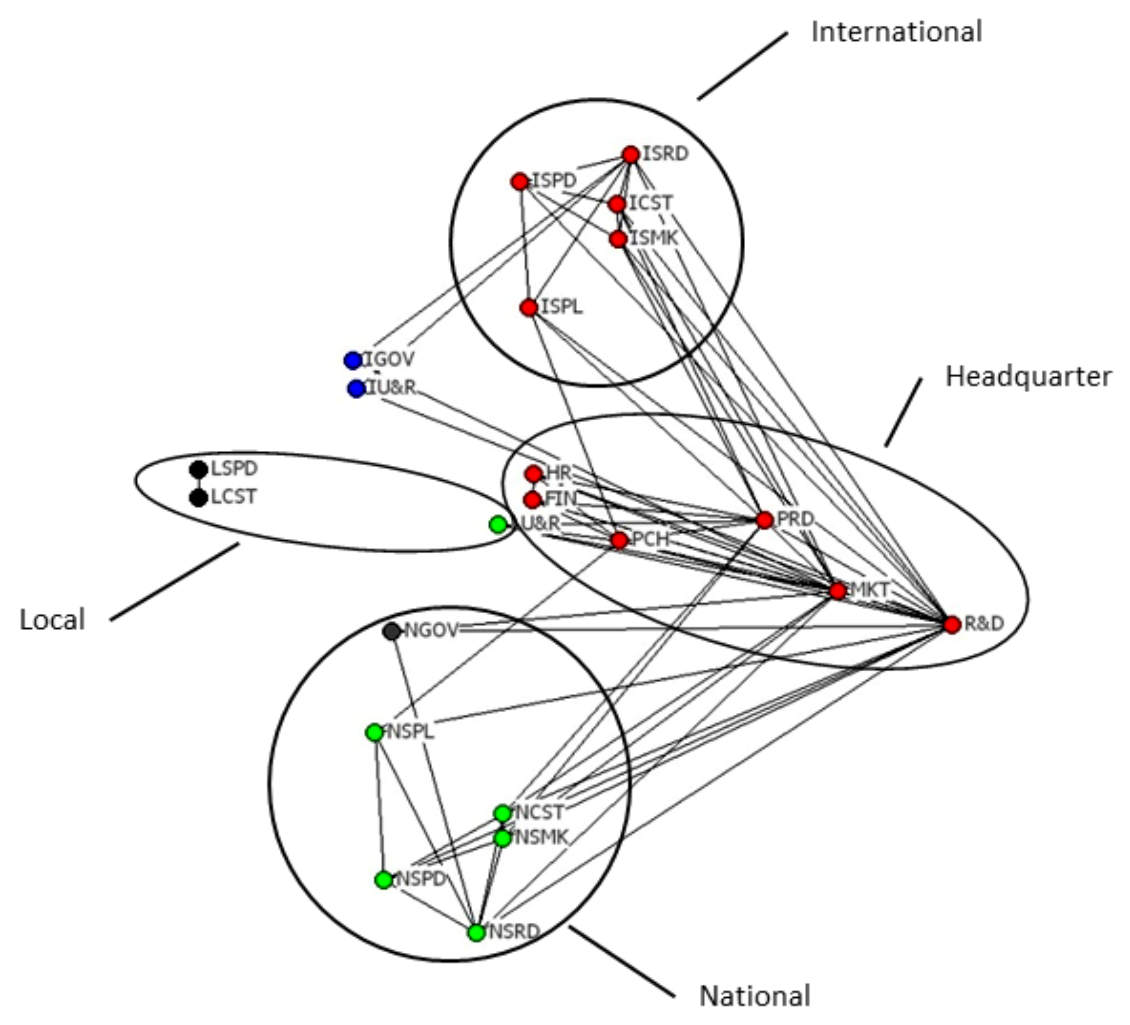

Figure 4. Structure of AUTO's GIN

The locally-organised characteristic of GINs and the great overlap between GINs and global production network (GPNs) in the case firm from a synthetic knowledge base industry is also verified by the VP of AUTO. He gave an example of such localisation of the global operation of AUTO.

"We have an internal supply chain. For example, a seat belt has different parts, the metal parts, the plastic parts, (and) the fabric parts. We have our own weaving facilities where we weave them. There are other internal suppliers working for seat belt production. The same is for the air bag. We have our own facilities for weaving the bag and for making the inflator. These connections are mainly in some regions. If you look into the map of our locations, you will see we have a bag facility in North 
America which supplies the needs of North America. We have a bag facility in China and Taiwan. They supply their region. We have the same in Europe. One is in UK and one in Poland. Then we have production facilities for different customers in Germany, France, Sweden, and some in Spain. They are buying from their internal suppliers in their regions. We have more consolidated production for the key components. There are subsidiaries for production which are also in a vertical line organized as tier one, tier two, and tier three. The tier one suppliers are our main supplier and they are the closest to the customers."

This statement suggests that due to the nature of the knowledge-base of this industry, even globalised networks (such as those of MNCs) reproduce, in the different locations, the same patterns of geographically close relations. That is, the $\mathrm{R} \& \mathrm{D}$ unit in a region internationally collaborates with the production and marketing unit co-located in that region, but also with the suppliers and customers of that particular region (see Figure 4).

\section{3. Models of structure of GINs}

With the results of the social network analysis (key connection analysis and structural equivalence analysis) and the evidence from the interviews conducted with the case companies, we identified two different models of structure of GINs, as shown in Figure 5, the globally-organised model of TELE's GIN and the locally-organised model of AUTO's GIN.

We explain differences in the structure of GINs by the different knowledge bases of the two industries within which the two case companies operate. The telecommunication industry is characterised by the analytic knowledge-base. In an analytic-knowledge-based industry, innovation is generated by radically new knowledge creation. R\&D plays a big role in the firm's operation. As the knowledge created in the industry is more standardized, codified and transferable, it makes it 
possible to organise innovation globally as the new knowledge is appropriate and applicable to innovation in different geographic locations. The automobile safety industry is more synthetically knowledge-based. In such industries, innovation usually comes from an application or novel combinations of existing knowledge. Applied and problem-solving related knowledge is more important. That is the reason why, in AUTO they distinguish between Research (4-6 years to production), Development (3-4 years to production) and Engineering (2 years to production). In that respect, they talk about $R \& D \& E$ rather than simply talk about $R \& D$ as most do.

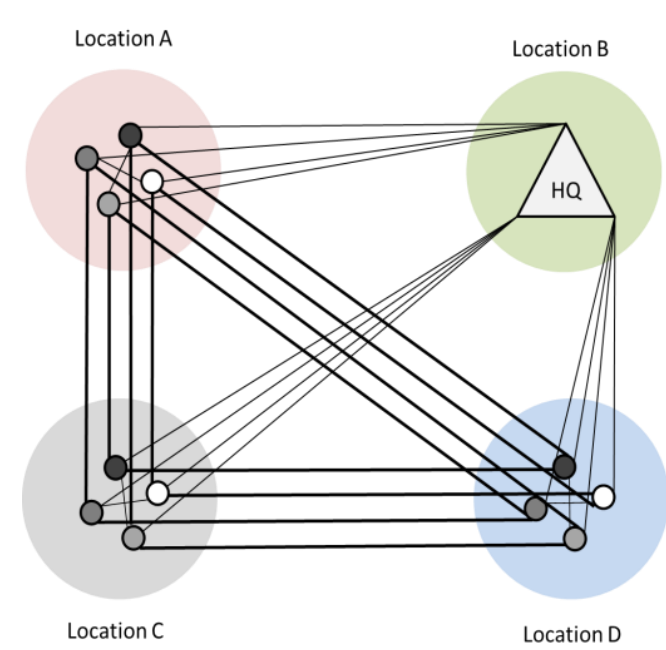

Globally-organised model of TELE

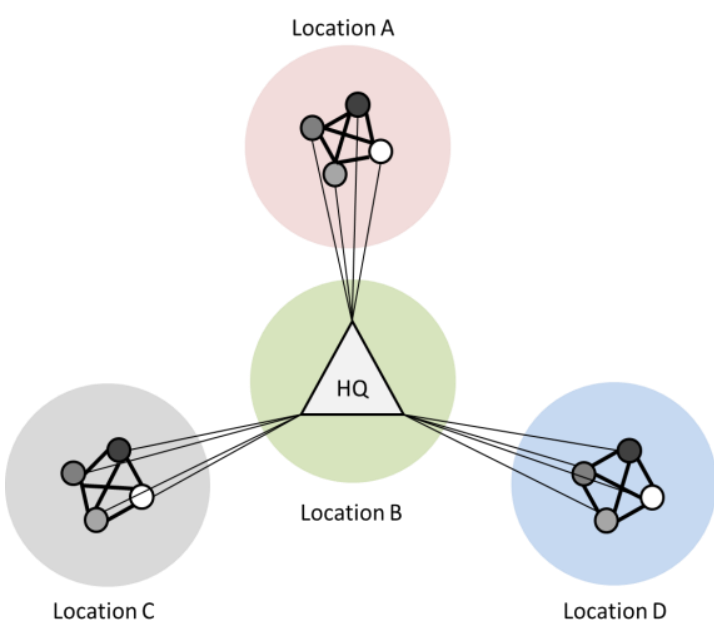

Locally-organised model of AUTO

Figure 5. Illustration of the different structures of GINs

In addition, R\&D usually refers to a small "r" and a big "D". Tacit knowledge, based on experiences, concrete know-how, craft and practical skills, seem to be more important to this industry than codified knowledge. This may be because innovative solutions generated in one location may not be applicable to another location. Innovation designed for a certain group of local customer based on their driving habits, the local road condition and traffic regulation may not be accepted by another 
group of customer in another country or region. Hence, it is sensible to organise innovation at a more local level but with strong controls from the headquarters. The last issue is also verified by the VP of AUTO:

"We have development which is generic development of new concepts and new systems. All of these developments we finance centrally. (...) Even though the development is done in Japan, in the US, in Europe, or in China and India, it is still under the coordination and order from our VP of engineering. The reason is that we want to avoid developing the same product in different places at the same time. We also want to strategically control what kind of product we want to develop and when it should come up to the market. So they are useful for all our markets even though they are developed in one market or one region. With all these generic products completed we can go out to the customer and quote. We would be asked what kind of seat belt we can offer to this new vehicle and then we would quote them our latest technology or what we think is the most suitable for both production and technical needs. After this we would run this application and engineering work. And we start the production."

\section{CONCLUSION}

The knowledge base literature, underpinning this paper, argues that due to different knowledge bases, industries will show different geographic patterns of knowledge sourcing. Firms in industries dominated by the analytical knowledge base will be more globally spread than firms in industries dominated by the synthetic knowledge base. We take this argument one step forward by investigating how MNCs (which by default are already globally spread) organise their innovation networks. We found that although innovation networks are similarly globally spread, the networks are organised very differently.

Our main argument is that the knowledge base dominating the industry in which a firm is operating strongly influences the geography and structure of its GIN. Firms in 
industries dominated by analytical knowledge base organise their innovation activities at a global scale, while firms in industries dominated by synthetic knowledge base regionalise their GINs.

Despite the increased globalisation, regions continue to be critical for innovation networks. But their role in GINs varies according to the nature of the knowledge-base in that particular industry. GINs in analytical knowledge-based industries are attracted to regions that have accumulated certain competences that are required for their research processes and that can only be acquired by "being there". But their embeddedness in the host region may not be as strong as in synthetic knowledgebased industries, as it does not imply other functions than R\&D. On the other hand, GINs in synthetic knowledge bases involve close linkages with production, suppliers and clients and are strongly organised at regional levels, even at a global scale. Although it is not explicitly addressed in this paper, the results also provide some insights on the interplay between GPNs and GINs. GINs in analytical-knowledge-d industries are driven by and organised around R\&D. Production departments are not part of the most important connections in the GIN which suggests that GINs may not necessarily overlap with GPNs in these industries. On the other hand, GINs in synthetic knowledge-base industries are organised around production departments, clients and suppliers, suggesting a clear overlap between GPNs and GINs.

One should be careful in generalising the results presented here. The way that firms organise their GINs is influenced by several determinants; the knowledge base is just one of them. In order to fully understand the structure and geography of firms' GINs, more research is needed on the determinants of the geography and structure of GINs as well as the interplay between GINs and GPNs.

Finally, one important policy implication of the increased importance of globally distributed innovation networks over the last decade is that it becomes more than ever vital for national and regional policy makers to understand how the global context interacts with the region- and sector-specific conditions in affecting innovativeness, competitiveness and economic growth. 
Acknowledgements: Research for this paper was partially funded by the European Community's Seventh Framework Programme (Project INGINEUS, Grant Agreement No.225368, www.ingineus.eu). The authors alone are responsible for its contents which do not necessarily reflect the views or opinions of the European Commission, nor is the European Commission responsible for any use that might be made of the information appearing herein. Additionally, financial support from the Swedish Research Council (Linneaus grant) is acknowledged. All errors remain exclusively of the authors. 


\section{REFERENCES}

ASHEIM, B. \& COENEN, L. (2005). Knowledge bases and regional innovation systems: Comparing Nordic clusters. Research Policy, 34, 1173.

ASHEIM, B., COENEN, L. \& VANG, J. (2007). Face-to-face, buzz, and knowledge bases: sociospatial implications for learning, innovation, and innovation policy. Environment and Planning C: Government and Policy, 25, $655-670$.

ASHEIM, B., COENEN, L. , Moodysson, J. \& VANG, J. (2007). Constructing knowledge-based regional advantage: implications for regional innovation policy. International Journal of Entrepreneurship and Innovation Management, 7, 140-155

ASHEIM, B. T. (2002). Temporary organisations and spatial embeddedness of learning and knowledge creation. Geografiska Annaler: Series B, Human Geography, 84, 111-124.

ASHEIM, B. T. \& GERTLER, M. S. (2005). The Geography of Innovation: Regional Innovation Systems. In: FAGERBERG, J., MOWERY, D. AND NELSON, R. (EDS.) (ed.) The Oxford Handbook of Innovation. Oxford: Oxford University Press.

ASHEIM, B. T. \& ISAKSEN, A. (1997). Location, agglomeration and innovation: towards regional innovation systems in Norway? European Planning Studies, 5, 299-330.

AUDRETSCH, D. B. \& FELDMAN, M. P. (1996). R\&D spillovers and the geography of innovation and production. The American Economic Review, 86, 630-640.

BARNARD, H. \& CHAMINADE, C. 2011. Global Innovation Networks: towards a taxonomy. CIRCLE Electronic Working Papers [Online]. Available: http://www.circle.lu.se [Accessed February 2012].

BATHELT, H., MALMBERG, A. \& MASKELL, P. (2004). Clusters and knowledge: local buzz, global pipelines and the process of knowledge creation. Progress in Human Geography, 28, 31-56.

BECATTINI, G. (1990). The Marshallian industrial district as a socio-economic notion. In: BECATTINI, G. (ed.) Industrial Districts and Inter-Firm Co-Operation in Italy. Geneva: International Institute for Labor Statistics.

BOSCHMA, R. (2005). Proximity and Innovation: A Critical Assessment. Regional Studies, 39, 6174.

BOSCHMA, R. \& FRENKEN, K. (2001). why is economic geography not an evolutionary science? Towards an evolutionary economic geography. Papers in Evolutionary Economic Geography. Uthecht University.

BORGATTI, S. P. and FOSTER, P.C. (2003). The network paradigm in organisational research: a review and typology, Journal of Management, 29, 991-1013.

CANTWELL, J. \& PISCITELLO, L. (2005). Recent Location of Foreign-owned Research and Development Activities by Large Multinational Corporations in the European Regions: The Role of Spillovers and Externalities. Regional Studies, 39, 1-16.

CANTWELL, J. \& PISCITELlO, L. (2007). Attraction and Deterrence in the Location of Foreign/owned R\&D activities: the role of positive and negative spillovers. International Journal of Technological Learning, Innovation and Development, 1, 83-111.

CASTELLANI, D. \& ZANFEI, A. (2006). Multinational firms, innovation and productivity, Edward Elgar Cheltenham.

CHAMINADE, C. \& VANG, J. (2008). Globalisation of knowledge production and regional innovation policy: Supporting specialized hubs in the Bangalore software industry. Research 
Policy, 37, 1684-1696.

CHEN, S.-H. (2004). Taiwanese IT firms' offshore R\&D in China and the connection with the global innovation network. Research Policy, 34, 337-349.

COE, N. M. \& BUNNELL, T. G. (2003). 'Spatializing'knowledge communities: towards a conceptualization of transnational innovation networks. Global networks, 3, 437-456.

COE, N. M., DICKEN, P. \& HESS, M. (2008). Introduction: global production networks - debates and challenges. Journal of Economic Geography, 8, 267-269.

COOKE, P. (1996). The new wave of regional innovation networks: analysis, characteristics and strategy. Small Business Economics, 8, 159-171.

DANKBAAR, B. (2007). Global sourcing and innovation: the consequences of losing both organizational and geographical proximity. European Planning Studies, 15, 271-288.

DE BRESSON, C. (1986). Technological clusters: poles of development. Paris: OCDE.

DICKEN, P. \& MALMBERG, A. (2001). Firms in Territories: A Relational Perspective*. Economic Geography, 77, 345-363.

DICKENS, P. (2007). Global Shifts: mapping the changing contours of the world economy, New York, Guilford.

ERNST, D. (2002). Global production Networks and the changing geography of innovation systems. Inplications for developing countries. Economics of Innovation and New Technology, 11, 497-523.

FELDMAN, M. (2000). Location and Innovation: The New Economic Geography of Innovation, Spillovers, and Agglomeration. In: CLACRK, G., FELDMAN, M. \& GERTLER, M. (eds.) The Oxford Handbook of Economic Geography (paperback edition 2003). Oxford: Oxford University Press.

FIFAREK, B. J. \& VELOSO, F. M. (2010). Offshoring and the global geography of innovation. Journal of Economic Geography, 10, 559.

FREEMAN, C. (1987). Technology policy and economic performance: lessons from Japan, London, Pinter.

GERTLER, M. (2008). Buzz Without Being There? Communities of Practice in Context. Community, Economic Creativity, and Organization, 1, 203-227.

GERTLER, M. S. \& LEVITTE, Y. M. (2005). Local Nodes in Global Networks: The Geography of Knowledge Flows in Biotechnology Innovation. Industry and Innovation, 12, 487-507.

GIULIANI, E. (2007). The selective nature of knowledge networks in clusters: evidence from the wine industry. Journal of Economic Geography, 7, 139-168.

GIULIANI, E., RABELOTTI, R. \& VAN DIJK, M. P. (2005). Clusters facing competition: the importance of external linkages, Aldershot and Burlington, Ashgate Publishing.

GRANT, R. (1996). Toward a knowledge-based theory of the firm. Strategic Management Journal, 17 (winter special issue), 109-122.

JICK, T. D. (1979). Mixing qualitative and quantitative methods: Triangulation in action. Administrative Science Quarterly, 24, 602-611.

LEWIN, A. Y., MASSINI, S. \& PEETERS, C. (2009). Why are companies offshoring innovation The emerging global race for talent. Journal of International Business Studies, 40, 901-925.

LISSONI, F. (2001). Knowledge codification and the geography of innovation: the case of Breschia mechanical cluster. Research Policy, 30, 1479-1500.

LOEBIS, L. \& SCHMITZ, H. (2005). Java furniture makers: winners or losers from globalisation? 
Development and practice. IDS, Sussex.

LOVE, J. H. \& ROPER, S. (2001). Location and network effects on innovation success: evidence for UK, German and Irish manufacturing plants. Research Policy, 30, 643-661.

LUNDVALL, B.-A. (ed.) (1992). National systems of innovation. Towards a theory of innovation and interactive learning., Londres: Pinter.

MARKUSEN, A. (1996). Sticky places in slippery space: a typology of industrial districts. Economic Geography, 72, 294-314.

MARTIN, R. \& MOODYSSON, J. (2011a). Comparing knowledge bases: on the geography and organization of knowledge sourcing in the regional innovation system of Scania, Sweden. European Urban and Regional Studies.

MARTIN, R. \& MOODYSSON, J. (2011b). Innovation in Symbolic Industries: The Geography and Organization of Knowledge Sourcing. European Planning Studies, 19, 1183-1203.

MOODYSSON, J. (2008). Principles and Practices of Knowledge Creation: On the Organization of" Buzz" and" Pipelines" in Life Science Communities. Economic Geography, 84, 449-469.

MOODYSSON, J., COENEN, L. \& ASHEIM, B. (2008). Explaining spatial patterns of innovation: analytical and synthetic modes of knowledge creation in the Medicon Valley life-science cluster. Environment and Planning A, 40, 1040-1056.

NADVI, K. \& SCHMITZ, H. (1999). Industrial clusters in developing countries. Special issue of World Development, 27.

NARULA, R. \& ZANFEI, A. (2004). Globalization of innovation: the role of multinational enterprises. In: FAGERBERG, J., MOWERY, D. \& NELSON, R. (eds.) The Oxford Handbook of Innovation. Oxford: OUP.

NELSON, R. (ed.) (1993). National innovation systems. A comparative analysis, Nueva York: Oxford Univ. Press.

NEWMAN, M.E.J. (2003), The structure and function of complex netowrks, SIAM Review, 45, 167 256

NIGHTINGALE, P. (1998). A cognitive model of innovation. Research Policy, 27, 689-709.

NONAKA, I. \& TAKEUCHI, H. (1995). The Knowledge-Creating Company, New York, Oxford University Press.

OECD (2001). Innovative clusters. Drivers of national innovation systems. Entreprise, Industry and service.

PORTER, M. E. (1998). Clusters and the new economics of competition. Harvard Business Review, 76, 77-90.

SCHMITZ, H. (2000). Does local co-operation matter? evidence from industrial clusters in South Asia and Latin America. Oxford Development Studies, 28, 323-336.

STERNBERG, R. (2000). Innovation networks and regional development-evidence from the European Regional Innovation Survey (ERIS): theoretical concepts, methodological approach, empirical basis and introduction to the theme issue. European Planning Studies, 8, 389-407.

STORPER, M. (1992). The limits to globalization: technology districs and international trade. Economic Geography, 68, 60-93.

STORPER, M. \& VENABLES, A. (2004). Buzz: face-to-face contact and the urban economy. Journal of Economic Geography, 4, 351.

WASSERMAN, S. \& FAUST, K. (1994). Social network analysis. Methods and applications, Cambridge, Cambridge University Press. 
ZANFEI, A. (2000). Transnational firms and the changing organisation of innovative activities. Cambridge Journal of Economics, 24, 515-542. 


\section{CIRCLE ELECTRONIC WORKING PAPERS SERIES (EWP)}

CIRCLE (Centre for Innovation, Research and Competence in the Learning Economy) is a multidisciplinary research centre set off by several faculties at Lund University and Blekinge Institute of Technology. CIRCLE has a mandate to conduct multidisciplinary research and education on the following issues: Long-term perspectives on innovation, structural change and economic growth, Entrepreneurship and venture capital formation with a special focus on new ventures, The dynamics of R\&D systems and technological systems, including their impact on entrepreneurship and growth, Regional innovation systems in different national and international contexts and International comparative analyses of national innovation systems. Special emphasis is done on innovation policies and research policies. 10 nationalities and 14 disciplines are represented among the CIRCLE staff.

The CIRCLE Electronic Working Paper Series are intended to be an instrument for early dissemination of the research undertaken by CIRCLE researchers, associates and visiting scholars and stimulate discussion and critical comment.

The working papers present research results that in whole or in part are suitable for submission to a refereed journal or to the editor of a book or have already been submitted and/or accepted for publication.

CIRCLE EWPs are available on-line at: http://www.circle.lu.se/publications

Available papers:

2013

WP 2013/01

Start-up rates, Entrepreneurship Culture and the Business Cycle Swedish patterns from national and regional data Martin Andersson

WP 2013/02

Market Thickness and the Early Labor Market Career of University Graduates -An urban advantage?

Lina Ahlin, Martin Andersson and Per Thulin

WP 2013/03

Implementing an R\&D Strategy without Prior R\&D-Experience - Recruitment as a Source of R\&D-related Routines and Capabilities?

Lina Ahlin, Martin Andersson and Thorben Schubert

WP 2013/04

The Choice of Innovation Policy Instruments

Susana Borrás, Charles Edquist

WP 2013/05

What Does Evolutionary Economic Geography Bring To The Policy Table? Reconceptualising regional innovation systems

Bjørn Asheim, Markus M. Bugge, Lars Coenen, Sverre Herstad

WP 2013/06

Commercializing clean technology innovations - the emergence of new business in an agency-structure perspective

Sofia Avdeitchikova, Lars Coenen

WP 2013/07

Renewal of mature industry in an old industrial region: regional innovation policy and the co-evolution of institutions and technology Lars Coenen, Jerker Moodysson and Hanna Martin

WP 2013/08

Systematic anchoring of global innovation processes and new industry formation - the emergence of on-site water recycling in China Christian Binz, Bernhard Truffer and Lars Coenen

WP 2013/09

The internationalisation of R\&D: sectoral and geographic patterns of cross-border investments

Cristina Castelli and Davide Castellani

WP 2013/10

Clean-tech innovation in Emerging Economies: Transnational dimensions in technological innovation system formation Jorrit Gosens, Yonglong Lu and Lars Coenen

WP 2013/11

Why space matters in technological innovation systems - the global knowledge dynamics of membrane bioreactor technology Christian Binz, Bernhard Truffer and Lars Coenen

WP 2013/12

MNC affiliation, knowledge bases and involvement in global innovation networks

Sverre J. Herstad, Bernd Ebersberger, Bjørn Asheim

WP 2013/13

System Failures, Knowledge Bases and Regional Innovation Policies

Roman Martin and Michaela Trippl

WP 2013/14

Differentiated Knowledge Bases and the Nature of Innovation Networks

Roman Martin

WP 2013/15

The Geography and Structure of Global Innovation Networks: A Knowledge Base Perspective

Ju Liu; Cristina Chaminade; Bjørn Asheim 
WP 2012/01

Is the University Model an Organizational Necessity? Scale and Agglomeration Effects in Science

Tasso Brandt and Torben Schubert

WP 2012/02

Do regions make a difference? Exploring the role of different regional innovation systems in global innovation networks in the ICT industry Cristina Chaminade and Monica Plechero

WP 2012/03

Measuring the knowledge base of regional innovation systems in Sweden

Roman Martin

WP 2012/04

Characteristics and Performance of New Firms and Spinoffs in Sweden

Martin Andersson and Steven Klepper

WP 2012/05

Demographic patterns and trends in patenting: Gender, age, and education of inventors

Olof Ejermo and Taehyun Jung

WP 2012/06

Competences as drivers and enablers of globalization of innovation: Swedish ICT industry and emerging economies

Cristina Chaminade and Claudia de Fuentes

WP 2012/07

The Dynamics and Evolution of Local Industries - The case of Linköping

Sabrina Fredin

WP2012/08

Towards a Richer Specification of the Exploration/Exploitation Trade-off: Hidden Knowledge-based Aspects and Empirical Results for a Set of Large R\&D-Performing Firms

Torben Schubert and Peter Neuhaeusler

WP 2012/09

The European Spallation Source (ESS) and the geography of innovation

Josephine V. Rekers

WP 2012/10

How Local are Spatial Density Externalities? - $\quad$ evidence from square grid data

Martin Andersson, Johan Klaesson, Johan P Larsson

WP 2012/11

Why Pre-Commercial Procurement is not Innovation Procurement

Charles Edquist, Jon Mikel Zabala-Iturriagagoitia

\section{1}

WP 2011/01

SMEs' absorptive capacities and large firms' knowledge spillovers: Micro evidence from Mexico

Claudia de Fuentes and Gabriela Dutrénit

WP 2011/02

Comparing knowledge bases: on the organisation and geography of knowledge flows in the regional innovation system of Scania, southern Sweden

Roman Martin and Jerker Moodysson

WP 2011/03

Organizational paths of commercializing patented inventions: The effects of transaction costs, firm capabilities, and collaborative ties Taehyun Jung and John P. Walsh

WP 2011/04

Global Innovation Networks: towards a taxonomy

Helena Barnard and Cristina Chaminade

WP 2011/05

Swedish Business R\&D and its Export Dependence

Karin Bergman and Olof Ejermo

WP 2011/06

Innovation Policy Design: Identification of Systemic Problems

Charles Edquist

WP 2011/07

Regional Institutional Environment and Its Impact on Intra-firm and Inter-organisational Innovation Networks: A Comparative Case Study in China and Switzerland

Ju LIU

WP 2011/08

Entrepreneurship: Exploring the Knowledge Base

Hans Landström, Gouya Harirchi and Fredrik Åström

WP 2011/09

Policy coordination in systems of innovation: A structural-functional analysis of regional industry support in Sweden

Magnus Nilsson and Jerker Moodysson

WP 2011/10

Urban Design in Neighbourhood Commodification

Ana Mafalda Madureira

WP 2011/11

Technological Dynamics and Social Capability: Comparing U.S. States and European Nations

Jan Fagerberg, Maryan Feldman and Martin Srhoelec

WP 2011/12

Linking scientific and practical knowledge in innovation systems

Arne Isaksen and Magnus Nilsson 
WP 2011/13

Institutional conditions and innovation systems: on the impact of regional policy on firms in different sectors

Jerker Moodysson and Elena Zukauskaite

WP 2011/14

Considering adoption: Towards a consumption-oriented approach to innovation

Josephine V. Rekers

WP2011/15

Exploring the role of regional innovation systems and institutions in global innovation networks

Cristina Chaminade

\section{$\underline{2010}$}

WP 2010/01

Innovation policies for development: towards a systemic experimentation based approach

Cristina Chaminade, Bengt-Ake Lundvall, Jan Vang-Lauridsen and KJ Joseph

WP 2010/02

From Basic Research to Innovation: Entrepreneurial Intermediaries for Research Commercialization at Swedish 'Strong Research Environments' Fumi Kitagawa and Caroline Wigren

WP 2010/03 Different competences, different modes in the globalization of innovation? A comparative study of the Pune and Beijing regions Monica Plechero and Cristina Chaminade

WP 2010/04 Technological Capability Building in Informal Firms in the Agricultural Subsistence Sector In Tanzania: Assessing the Role of Gatsby Clubs

Astrid Szogs and Kelefa Mwantima

WP 2010/05

The Swedish Paradox - Unexploited Opportunities

Charles Edquist

WP 2010/06

A three-stage model of the Academy-Industry linking process: the perspective of both agents

Claudia De Fuentes and Gabriela Dutrénit

WP 2010/07

Innovation in symbolic industries: the geography and organisation of knowledge sourcing

Roman Martin and Jerker Moodysson

WP 2010/08

Towards a spatial perspective on sustainability transitions

Lars Coenen, Paul Benneworth and Bernhard Truffer

WP 2010/09

The Swedish national innovation system and its relevance for the emergence of global innovation networks

Cristina Chaminade, Jon Mikel Zabala and Adele Treccani

WP 2010/10

Who leads Research Productivity Change? Guidelines for R\&D policy makers

Fernando Jiménez-Sáez, Jon Mikel Zabala and José L- Zofío

WP 2010/11

Research councils facing new science and technology

Frank van der Most and Barend van der Meulen

WP 2010/12

Effect of geographical proximity and technological capabilities on the degree of novelty in emerging economies

Monica Plechero

WP 2010/13

Are knowledge-bases enough? A comparative study of the geography of knowledge sources in China (Great Beijing) and India (Pune) Cristina Chaminade

WP 2010/14

Regional Innovation Policy beyond 'Best Practice': Lessons from Sweden

Roman Martin, Jerker Moodysson and Elena Zukauskaite

WP 2010/15

Innovation in cultural industries: The role of university links

Elena Zukauskaite

WP 2010/16

Use and non-use of research evaluation. A literature review

Frank van der Most

WP 2010/17

Upscaling emerging niche technologies in sustainable energy: an international comparison of policy approaches

Lars Coenen, Roald Suurs and Emma van Sandick

\section{9}

WP 2009/01

Building systems of innovation in less developed countries: The role of

intermediate organizations.

Szogs, Astrid; Cummings, Andrew and Chaminade, Cristina

WP 2009/02

The Widening and Deepening of Innovation Policy: What Conditions Provide for Effective Governance?

Borrás, Susana

WP 2009/03

Managerial learning and development in small firms: implications based on observations of managerial work 
WP 2009/04

University professors and research commercialization: An empirical test of the "knowledge corridor" thesis

Gabrielsson, Jonas, Politis, Diamanto and Tell, Joakim

WP 2009/05

On the concept of global innovation networks

Chaminade, Cristina

WP 2009/06

Technological Waves and Economic Growth - Sweden in an International Perspective 1850-2005

Schön, Lennart

\section{WP 2009/07}

Public Procurement of Innovation Diffusion: Exploring the Role of Institutions and Institutional Coordination Rolfstam, Max; Phillips, Wendy and Bakker, Elmer

WP 2009/08

Local niche experimentation in energy transitions: a theoretical and empirical exploration of proximity advantages and disadvantages

Lars Coenen, Rob Raven, Geert Verbong

WP 2009/9

Product Development Decisions: An empirical approach to Krishnan and Ulrich

Jon Mikel Zabala, Tina Hannemann

WP 2009/10

Dynamics of a Technological Innovator Network and its impact on technological performance

Ju Liu, Cristina Chaminade

WP 2009/11

The Role of Local Universities in Improving Traditional SMEs Innovative Performances: The Veneto Region Case Monica Plechero

WP 2009/12

Comparing systems approaches to innovation and technological change for sustainable and competitive economies: an explorative study into conceptual commonalities, differences and complementarities

Coenen, Lars and Díaz López, Fernando $J$.

WP 2009/13

Public Procurement for Innovation (PPI) - a Pilot Study

Charles Edquist

WP 2009/14

Outputs of innovation systems: a European perspective

Charles Edquist and Jon Mikel Zabala

\section{8}

WP 2008/01

$R \& D$ and financial systems: the determinants of $R \& D$ expenditures in the Swedish pharmaceutical industry

Malmberg, Claes

WP 2008/02

The Development of a New Swedish Innovation Policy. A Historical Institutional Approach

Persson, Bo

WP 2008/03

The Effects of R\&D on Regional Invention and Innovation

Olof Ejermo and Urban Gråsjö

WP 2008/04

Clusters in Time and Space: Understanding the Growth and Transformation of

Life Science in Scania

Moodysson, Jerker; Nilsson, Magnus; Svensson Henning, Martin

WP 2008/05

Building absorptive capacity in less developed countries

The case of Tanzania

Szogs, Astrid; Chaminade, Cristina and Azatyan, Ruzana

WP 2008/06

Design of Innovation Policy through Diagnostic Analysis:

Identification of Systemic Problems (or Failures)

Edquist, Charles

WP 2008/07

The Swedish Paradox arises in Fast-Growing Sectors

Ejermo, Olof; Kander, Astrid and Svensson Henning, Martin

WP 2008/08

Policy Reforms, New University-Industry Links and Implications for Regional Development in Japan

Kitagawa, Fumi

WP 2008/09

The Challenges of Globalisation: Strategic Choices for Innovation Policy

Borrás, Susana; Chaminade, Cristina and Edquist, Charles

WP 2008/10

Comparing national systems of innovation in Asia and Europe: theory and comparative framework

Edquist, Charles and Hommen, Leif

WP 2008/11

Putting Constructed Regional Advantage into Swedish Practice? The case of the VINNVÄXT initiative 'Food Innovation at Interfaces' Coenen, Lars; Moodysson, Jerker

WP 2008/12

Energy transitions in Europe: 1600-2000

Kander, Astrid; Malanima, Paolo and Warde, Pau 
WP 2008/13

RIS and Developing Countries: Linking firm technological capabilities to regional systems of innovation

Padilla, Ramon; Vang, Jan and Chaminade, Cristina

WP 2008/14

The paradox of high R\&D input and low innovation output: Sweden

Bitarre, Pierre; Edquist, Charles; Hommen, Leif and Ricke, Annika

WP 2008/15

Two Sides of the Same Coin? Local and Global Knowledge Flows in Medicon Valley

Moodysson, Jerker; Coenen, Lars and Asheim, Bjørn

WP 2008/16

Electrification and energy productivity

Enflo, Kerstin; Kander, Astrid and Schön, Lennart

WP 2008/17

Concluding Chapter: Globalisation and Innovation Policy

Hommen, Leif and Edquist, Charles

WP 2008/18

Regional innovation systems and the global location of innovation activities: Lessons from China

Yun-Chung, Chen; Vang, Jan and Chaminade, Cristina

WP 2008/19

The Role of mediator organisations in the making of innovation systems in least developed countries. Evidence from Tanzania

Szogs, Astrid

WP 2008/20

Globalisation of Knowledge Production and Regional Innovation Policy:

Supporting Specialized Hubs in the Bangalore Software Industry

Chaminade, Cristina and Vang, Jan

WP 2008/21

Upgrading in Asian clusters: Rethinking the importance of interactive-learning

Chaminade, Cristina and Vang, Jan

\section{7}

WP 2007/01

Path-following or Leapfrogging in Catching-up: the Case of Chinese Telecommunication Equipment Industry Liu, Xielin

WP 2007/02

The effects of institutional change on innovation and productivity growth in the Swedish pharmaceutical industry Malmberg, Claes

WP 2007/03

Global-local linkages, Spillovers and Cultural Clusters: Theoretical and Empirical insights from an exploratory study of Toronto's Film Cluste Vang, Jan; Chaminade, Cristina

WP 2007/04

Learning from the Bangalore Experience: The Role of Universities in an Emerging Regional Innovation System

Vang, Jan; Chaminade, Cristina.; Coenen, Lars.

WP 2007/05

Industrial dynamics and innovative pressure on energy -Sweden with European and Global outlooks

Schön, Lennart; Kander, Astrid.

WP 2007/06

In defence of electricity as a general purpose technology

Kander, Astrid; Enflo, Kerstin; Schön, Lennart

WP 2007/07

Swedish business research productivity - improvements against international trends

Ejermo, Olof; Kander, Astrid

WP 2007/08

Regional innovation measured by patent data - does quality matter?

Ejermo, Olof

WP 2007/09

Innovation System Policies in Less Successful Developing countries: The case of Thailand

Intarakumnerd, Patarapong; Chaminade, Cristina

$\underline{2006}$

WP 2006/01

The Swedish Paradox

Ejermo, Olof; Kander, Astrid

WP 2006/02

Building RIS in Developing Countries: Policy Lessons from Bangalore, India

Vang, Jan; Chaminade, Cristina

WP 2006/03

Innovation Policy for Asian SMEs: Exploring cluster differences

Chaminade, Cristina; Vang, Jan.

WP 2006/04

Rationales for public intervention from a system of innovation approach: the case of VINNOVA.

Chaminade, Cristina; Edquist, Charles

WP 2006/05

Technology and Trade: an analysis of technology specialization and export flows

Andersson, Martin; Ejermo, Olof 
WP 2006/06

A Knowledge-based Categorization of Research-based Spin-off Creation

Gabrielsson, Jonas; Landström, Hans; Brunsnes, E. Thomas

WP 2006/07

Board control and corporate innovation: an empirical study of small technology-based firms

Gabrielsson, Jonas; Politis, Diamanto

WP 2006/08

On and Off the Beaten Path:

Transferring Knowledge through Formal and Informal Networks

Rick Aalbers; Otto Koppius; Wilfred Dolfsma

WP 2006/09

Trends in R\&D, innovation and productivity in Sweden 1985-2002

Ejermo, Olof; Kander, Astrid

WP 2006/10

Development Blocks and the Second Industrial Revolution, Sweden 1900-1974

Enflo, Kerstin; Kander, Astrid; Schön, Lennart

WP 2006/11

The uneven and selective nature of cluster knowledge networks: evidence from

the wine industry

Giuliani, Elisa

WP 2006/12

Informal investors and value added: The contribution of investors' experientially acquired resources in the entrepreneurial process

Politis, Diamanto; Gabrielsson, Jonas

WP 2006/13

nformal investors and value added: What do we know and where do we go?

Politis, Diamanto; Gabrielsson, Jonas

WP 2006/14

Inventive and innovative activity over time and geographical space: the case of

Sweden

Ejermo, Olof

$\underline{2005}$

WP 2005/1

Constructing Regional Advantage at the Northern Edge

Coenen, Lars; Asheim, Bjørn

WP 2005/02

From Theory to Practice: The Use of the Systems of Innovation Approach for Innovation Policy

Chaminade, Cristina; Edquist, Charles

WP 2005/03

The Role of Regional Innovation Systems in a Globalising Economy: Comparing Knowledge Bases and Institutional Frameworks in Nordic Clusters

Asheim, Bjørn; Coenen, Lars

WP 2005/04

How does Accessibility to Knowledge Sources Affect the Innovativeness of Corporations? Evidence from Sweden

Andersson, Martin; Ejermo, Olof

WP 2005/05

Contextualizing Regional Innovation Systems in a Globalizing Learning Economy: On Knowledge Bases and Institutional Frameworks

Asheim, Bjørn; Coenen, Lars

WP 2005/06

Innovation Policies for Asian SMEs: An Innovation Systems Perspective

Chaminade, Cristina; Vang, Jan

WP 2005/07

Re-norming the Science-Society Relation

Jacob, Merle

WP 2005/08

Corporate innovation and competitive environment

Huse, Morten; Neubaum, Donald O.; Gabrielsson, Jonas

WP 2005/09

Knowledge and accountability: Outside directors' contribution in the corporate value chain

Huse, Morten, Gabrielsson, Jonas; Minichilli, Alessandro

WP 2005/10

Rethinking the Spatial Organization of Creative Industries

Vang, Jan

WP 2005/11

Interregional Inventor Networks as Studied by Patent Co-inventorships

Ejermo, Olof; Karlsson, Charlie

WP 2005/12

Knowledge Bases and Spatial Patterns of Collaboration: Comparing the Pharma and Agro-Food Bioregions Scania and Saskatoon Coenen, Lars; Moodysson, Jerker; Ryan, Camille; Asheim, Bjørn; Phillips, Peter

WP 2005/13

Regional Innovation System Policy: a Knowledge-based Approach

Asheim, Bjørn; Coenen, Lars; Moodysson, Jerker; Vang, Jan

WP 2005/14

Face-to-Face, Buzz and Knowledge Bases: Socio-spatial implications for learning and innovation policy

Asheim, Bjørn; Coenen, Lars, Vang, Jan

WP 2005/15 
The Creative Class and Regional Growth: Towards a Knowledge Based Approach Kalsø Hansen, Høgni; Vang, Jan; Bjørn T. Asheim

\section{5/16}

Emergence and Growth of Mjärdevi Science Park in Linköping, Sweden Hommen, Leif; Doloreux, David; Larsson, Emma

WP 2005/17

Trademark Statistics as Innovation Indicators? - A Micro Study Malmberg, Claes 